\title{
Ferrocement and Convention Soil Retaining Structure Observation using Geometrical Configuration
}

\author{
Shubhashree R. Chimote, Prashant D. Hiwase
}

\begin{abstract}
The conventional RCC soil retaining structure has got its certain drawbacks of being too heavy and costly. This paper deals with use of ferrocement as an alternative to conventional RCC soil retaining structure. An analytical study is carried out using Ansys 17.0 software to compare ferrocement soil retaining structure with geometrically identical Conventional RCC soil retaining structure. Ferrocement is advantageously used for its less thickness and flexibility to mould in required shapes. We can use full sectional strength of ferrocement in analysis of structure using optimum geometrical configuration. In the research work, Conventional RCC structure is also compared with rectangular and arch shaped ferrocement soil retaining structure of $50 \mathrm{~mm}$ thickness and $5 \mathrm{~m}$ height, with a retaining soil density of $18 \mathrm{kN} / \mathrm{m} 3$. The results showed that in arch shaped face and base wall structure, deflection and stresses are very less and within permissible limits. Due to reduced thickness of members, requirement of material is less and thus found to be more cost-effective than RCC soil retaining structure.

Index Terms - geometrical configuration, ferrocement, soil retaining structure, arch shaped retaining wall
\end{abstract}

\section{INTRODUCTION}

Ferrocement is a composite material which is made up of cement mortar reinforced with closely spaced layers of steel wire meshes distributed throughout the mortar. The continuity in placement of equal mesh reinforcement in both directions make ferrocement able to achieve equal strength moulded in any shape and size and also formless construction. In RCC steel bars are embedded in a concrete while in ferrocement wire meshes are filled in with mortar which increases contact area of reinforcement and mortar, therefore higher bond strength can be achieved. So ferrocement is good alternative in which time for construction and cost can be reduced as compared to RCC counterfort retaining wall. Before selecting ferrocement as a alternative material study of past work related to ferrocement has been carried out [1] sunil kumar and N.jayaramappa; evaluated strength and modulus of elasticity slabs of $600 \mathrm{~mm} \mathrm{X} 600 \mathrm{~mm}$ and six slab panels of $250 \mathrm{~mm} \mathrm{X}$ $250 \mathrm{~mm}$ both having $40 \mathrm{~mm}$ thickness with varying volume of reinforcement are tested under two-point loading test also

Revised Manuscript Received on July 10, 2019.

Shubhashree R. Chimote, M. Tech (Structural Engineering), Department of Civil Engineering, Shri Ramdeobaba college of Engineering and Management, Nagpur, Maharashtra, India. (E-mail: shubhashreechimote123@gmail.com)

Prashant D. Hiwase, Assistant Professor, Department of Civil Engineering, Shri Ramdeobaba college of Engineering and Management, Nagpur, Maharashtra, India. (E-mail: Prashant.hiwase@gmail.com) in that directions. It is a thin walled construction and can be of ferrocement slab panels experimentally. Nine ferrocement

compared with RCC slab panel and author concluded that with increasing percentage of volume of reinforcement, load carrying capacity of member increases. RCC slab panel contains only $1.7 \%$ more strength than four layered ferrocement slab panel.[2] Hamis eskandari and amirhossein madad their study provides an experimental analysis of ferrocement channel of span $4.5 \mathrm{~m}$ and width $70 \mathrm{~cm}$ and finite element analysis of channel for different support systems and beam spans. Analysis is done by applying surface loading and author concludes that fixed support is the best support by proving arch shape material can resist more compressive loads, value of deflection also get reduced.[3] Girish p. Dhotre author has done experimental analysis over arch shape counterfort retaining wall and cost comparison of RCC cantilever, counterfort and ferrocement arch shape counterfort retaining wall was done. Ferrocement arch shape base and heel counterfort retaining wall of height $1.5 \mathrm{~m}$, arch rise of $0.2 \mathrm{~m}$ and thickness of $0.04 \mathrm{~m}$ is casted and deflections at various points were calculated using strain gauges for different loading condition. He concluded that in ferrocement arched shaped counterfort retain9ng wall maximum deflection is observed at top of heel and ferrocement retaining wall found to be more economical than RCC cantilever and counterfort retaining wall.

\section{METHODOLOGY}

2.1 In the study of comparison between RCC counterfort and ferrocement counterfort retaining wall to know about structural behaviour of the wall, analysis is done by finite element method of analysis using ANSYS workbench 17.0 software.

2.2 To confirm the accuracy of work results in above software for ferrocement element, validation using previous experimental work has been carried out. In validation one slab panel is prepared according to given dimensions with given loading and supporting condition and results of load verses deflection is evaluated in software and it is compared with experimental paper work results.

2.3(a) In current research work for comparing Reinforced Cement Concrete structure with Ferrocement structure, retaining wall of $5 \mathrm{~m}$ height with soil density of $18 \mathrm{kN} / \mathrm{m} 3$ is considered. For Reinforced Cement Concrete retaining wall other dimensions of structure is calculated by manual analysis, thickness of each member is calculated be using

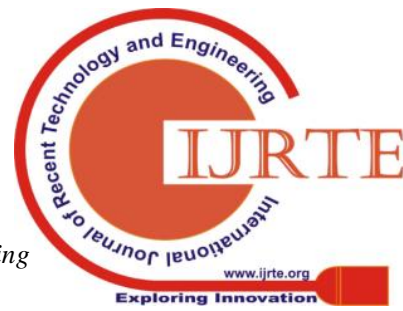


moment equilibrium equation. Value of young's modulus of elasticity is taken as $22360.67 \mathrm{~N} / \mathrm{mm} 2$ for grade of concrete M20 and density of RCC taken as $25000 \mathrm{~N} / \mathrm{mm}^{2}$. from this data rectangular RCC structure is modelled in ANSYS workbench 17.0. Backfill is considered as horizontal, depth of backfill is equals to total depth of stem, loads are applied over stem and base according to given density of soil.

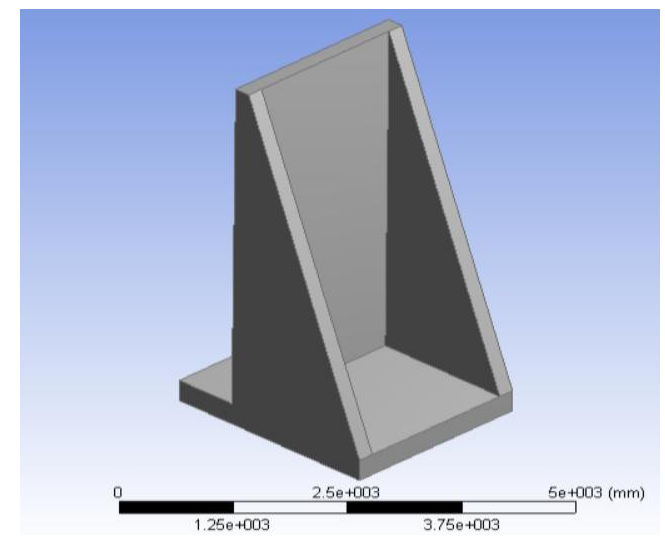

Fig. 1 Conventional RCC Retaining Structure

2.3(b) After this ferrocement retaining wall of equivalent dimensions as measured for RCC with grade of concrete M20 and properties of welded square mesh as a reinforcement having yielding stress $450 \quad \mathrm{~N} / \mathrm{mm}^{2}$, considering modulus of elasticity of composite material as $30000 \mathrm{~N} / \mathrm{mm}^{2}$.with these properties rectangular ferrocement wall is modelled in software with same dimensions and results are analysed.

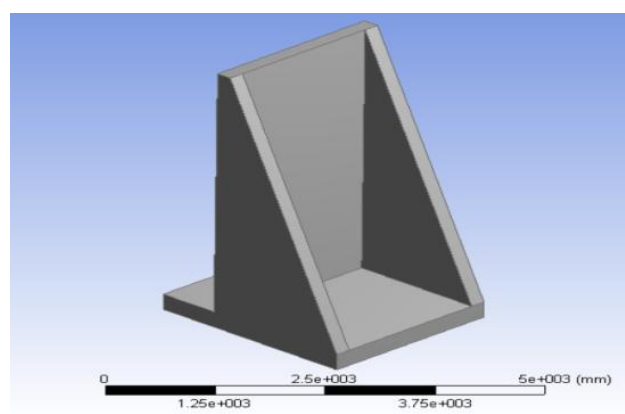

Fig 2. Ferrocement Rectangular Retaining Wall Of Same Dimension As RCC

2.3(c)Ferrocement wall thickness hardly exceeds $50 \mathrm{~mm}$. it is the material consist of sprayed mesh layers throughout the member which helps in increase in flexural strength and reduced thickness of member. Then, keeping material properties same for ferrocement rectangular retaining wall, again rectangular retaining wall of only $50 \mathrm{~mm}$ thickness of base, stem and counterforts is modelled and results are analysed.

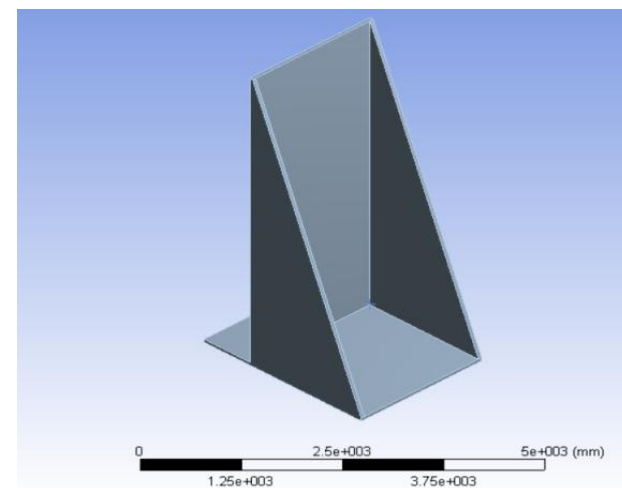

Fig. 3 Ferrocement Rectangle Retaining Wall of 50 mm Thick

2.3(d) After this to confirm the best geometrical configuration of the structure as ferrocement structures can be shaped in such a way that the full section of the member and the full strength of material can be utilized, so its stem is shaped into an arch to achieve higher compressive strength of mortar and full cross section of arch sharing the load. For arch shape stem rise of arch is considered as $500 \mathrm{~mm}$, clear distance between counterforts is $2000 \mathrm{~mm}$ then for calculating radius of curvature of arch, chord intersecting property is used and radius of arch found out to be $1250 \mathrm{~mm}$ with apex angle is $108^{\circ}$ giving arch length $2356 \mathrm{~mm}$. Considering all the specification of arch for stem and keeping base of rectangular shape ferrocement counterfort retaining wall with $50 \mathrm{~mm}$ thickness of whole structure is modelled and after applying loads and fixed support to base results are evaluated.

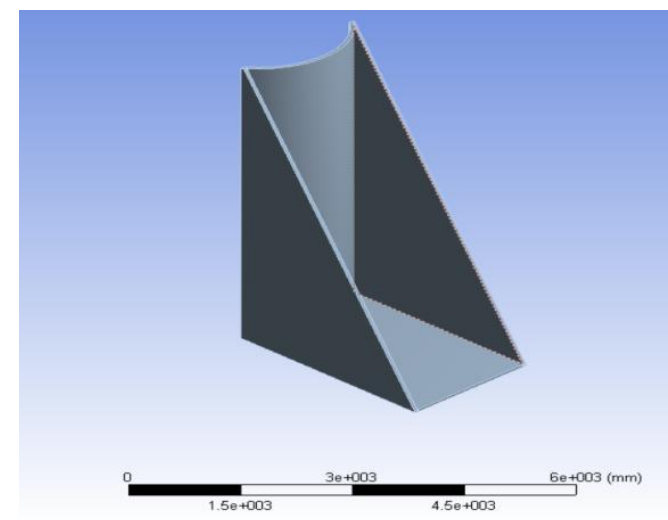

Fig. 4 Ferrocement Arch Stem and Flat Base Retaining Wall of $50 \mathrm{~mm}$ Thick

2.3(e) After this, one more retaining wall in which stem as well as base is also taken in arch shape with radius of $1250 \mathrm{~mm}$ having thickness $50 \mathrm{~mm}$ and rise as $500 \mathrm{~mm}$. Considering all this, results are evaluated. in above all types of retaining wall loading is same over the stem and base, triangular loading is applied over stem and uniformly distributed load over heel and toe of $84.6 \mathrm{kN} / \mathrm{m}^{2}$ and 12.6 $\mathrm{kN} / \mathrm{m}^{2}$ respectively. Fixed support is provided to base of all counterfort retaining wall. Deflection and direct stresses are evaluated under stem, base and counterforts at various position in each of these member and graphs are plotted.

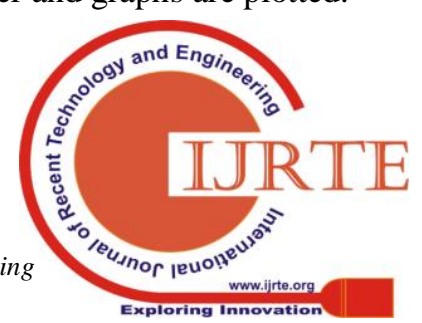




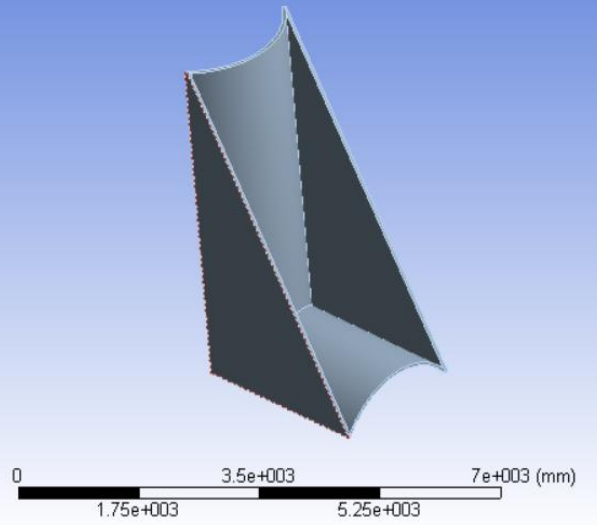

Fig.5 Ferrocement Arch Stem and Base Retaining Wall Of 50mm Thick

\section{RESULTS AND COMPARISION}

After analysing all the types of retaining wall comparative results are shown for each member at various positions

Table 1. Values of deflection and direct stresses under stem at various position

\begin{tabular}{|c|c|c|c|c|c|c|c|}
\hline \multirow{2}{*}{$\begin{array}{l}\mathrm{St} \\
\text { no }\end{array}$} & \multirow[t]{2}{*}{ Type of wall } & \multicolumn{3}{|c|}{ Deflection in mm } & \multicolumn{3}{|c|}{ Direct stress in $\mathrm{MPa}$} \\
\hline & & top & Middle & bottom & Top & Middle & bottom \\
\hline 1 & $\mathrm{RCC}$ & 0 & 0 & 0 & 0.0102 & 0.196 & 0.087 \\
\hline 2 & $\begin{array}{c}\text { Ferrocement wall } \\
\text { of same } \\
\text { dimension }\end{array}$ & 0.0512 & 0.073 & 0 & 0.0201 & 0.248 & 0.115 \\
\hline 3 & $\begin{array}{c}\text { Ferrocement } \\
\text { rectangular of } 50 \\
\text { mm thickness }\end{array}$ & 1.14 & 3.43 & 0 & 0.52 & 1.22 & 3.2 \\
\hline 4 & $\begin{array}{l}\text { Ferrocement arch } \\
\text { stem retaining } \\
\text { wall } 50 \mathrm{~mm} \\
\text { thickness }\end{array}$ & 0.767 & 0.511 & 0 & 0.094 & 0.125 & 0.433 \\
\hline 5 & $\begin{array}{l}\text { Ferrocement arch } \\
\text { stem and base } \\
\text { retaining wall }\end{array}$ & .029 & 0.016 & 0 & 0.0469 & 0.0243 & 0.3 \\
\hline
\end{tabular}

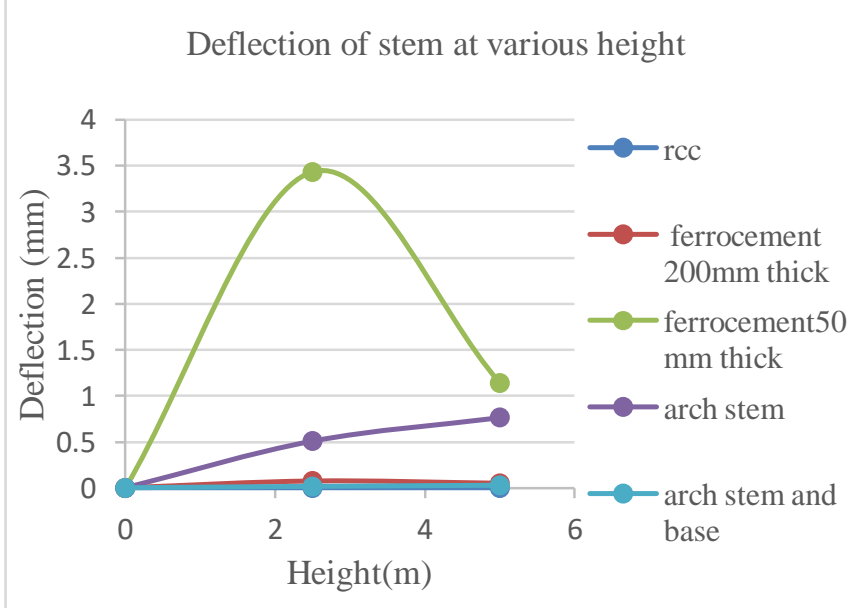

Graph 1(a) Representing Values of Deflection Under Stem for All Types of Retaining Wall.

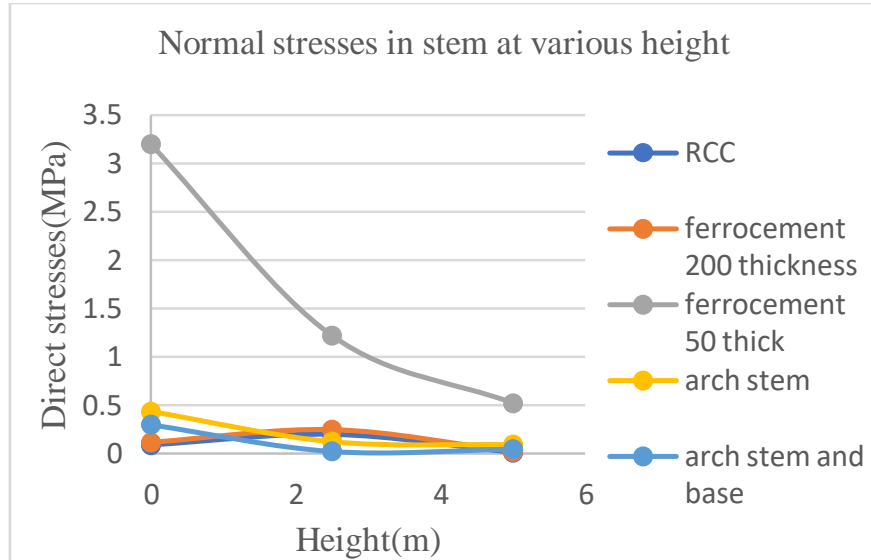

Graph 1(b) Representing Values Of Direct Stresses Under Stem For All Types Of Retaining Wall.

Table 2: Deflection and Direct Stresses Values in Counterfort at Various Height.

\begin{tabular}{|c|c|c|c|c|c|c|c|}
\hline \multirow{2}{*}{$\begin{array}{c}\text { Sr } \\
\text { no }\end{array}$} & Type of wall & \multicolumn{3}{|c|}{ Deflection $(\mathrm{mm})$} & \multicolumn{3}{c|}{ Direct stress (MPa) } \\
\cline { 3 - 8 } & RCC & 0 & 0 & 0 & 0.0288 & 0.196 & 0.0288 \\
\hline 1 & top & middle & bottom & Top & middle & bottom \\
\hline 2 & $\begin{array}{c}\text { Ferrocement } \\
\text { wall of same } \\
\text { dimension }\end{array}$ & 0.042 & 0.068 & 0 & 0.0201 & 0.248 & 0.0201 \\
\hline 3 & $\begin{array}{c}\text { Ferrocement } \\
\text { rectangular of } \\
50 \text { mm } \\
\text { thickness }\end{array}$ & 0.76 & 3.43 & 0 & 0.52 & 4.2 & 1.44 \\
\hline & $\begin{array}{c}\text { Ferrocement } \\
\text { arch stem } \\
\text { retaining wall } \\
50 \text { mm } \\
\text { thickness }\end{array}$ & 0.42 & 0.68 & 0 & 0.26 & 0.94 & 0.094 \\
\hline 5 & $\begin{array}{c}\text { Ferrocement } \\
\text { arch stem and } \\
\text { base retaining } \\
\text { wall }\end{array}$ & 0.0163 & 0.023 & 0 & 0.046 & 0.468 & 0.0865 \\
\hline
\end{tabular}

Deformation in counterfort at various height

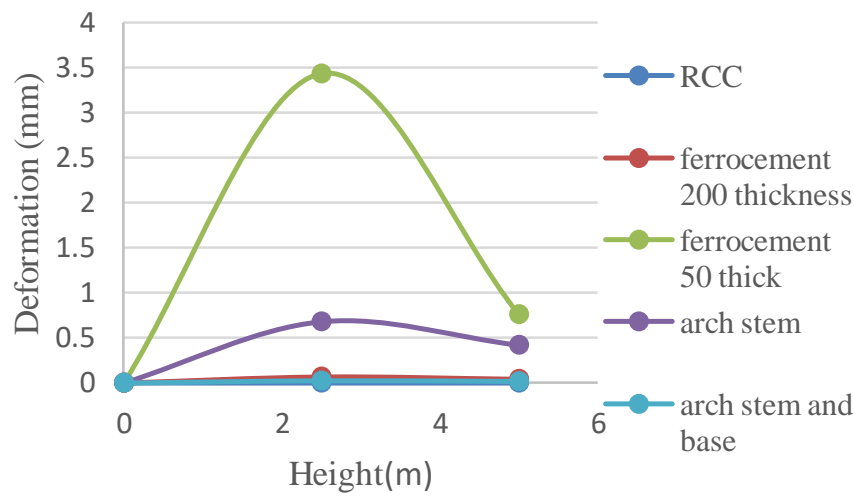

Graph 2(a) Representing Values of Deflection Under Counterfort for All Types of Retaining Wall. 
Direct stresses in counterfort at various height

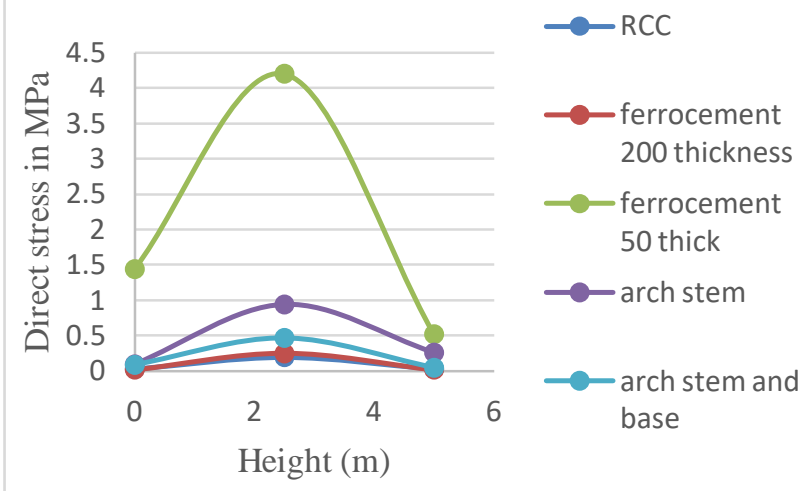

Graph 2(b) Representing Values of Direct Stresses Under Counterfort for All Types of Retaining Wall.

Table 3: Direct Stress Values at Base of Retaining Wall

\begin{tabular}{|c|c|c|c|c|}
\hline \multirow{2}{*}{ Sr no } & Type of wall & \multicolumn{3}{|c|}{ Direct stresses in $\mathrm{MPa}$} \\
\cline { 3 - 5 } & RCC & 0.0102 & 0.087 & 0.0288 \\
\hline 1 & toe & joint & heel \\
\hline 2 & $\begin{array}{c}\text { Ferrocement wall of } \\
\text { same dimension }\end{array}$ & 0.0201 & 0.115 & 0.0201 \\
\hline 3 & $\begin{array}{c}\text { Ferrocement } \\
\text { rectangular of 50 mm } \\
\text { thickness }\end{array}$ & 0.52 & 3.2 & 0.52 \\
\hline 4 & $\begin{array}{c}\text { Ferrocement arch } \\
\text { stem retaining wall } \\
50 \text { mm thickness }\end{array}$ & 0.0949 & 0.433 & 0.069 \\
\hline 5 & $\begin{array}{c}\text { Ferrocement arch } \\
\text { stem and base } \\
\text { retaining wall }\end{array}$ & 0.034 & 0.3 & 0.046 \\
\hline
\end{tabular}

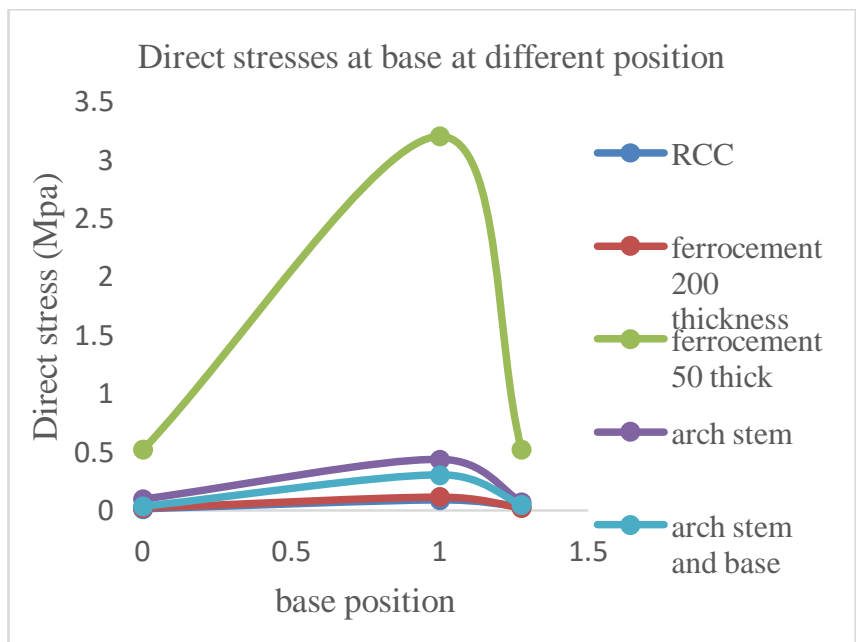

Graph 3 Representing Values of Direct Stresses Under Base At Various Positions

\section{CONCLUSIONS}

In RCC structure under the loading after first crack concrete and steel behaves separately while in ferrocement, steel meshes used as reinforcing material is dispersed throughout the structure due to strong bond between wire meshes and mortar even after first crack steel and mortar act together as a homogeneous material. This shows ductile properties of material. Hence deflection limit under limit state of collapse is considered which allows $20 \mathrm{~mm}$ deflection and as we are using grade of mortar M20 its permissible limit of direct stress is $5 \mathrm{MPa}$ from IS 456-2000. Following are the results showing various values of deflection and direct stresses under stem base and counterforts at different position of these member.

1. In rectangular shape counterfort retaining wall maximum deflection is observed at $h / 3$ distance on stem while in arch shape counterfort retaining wall maximum deflection is observed at top surface of stem.

2. Very large deflections and maximum value of direct stress are observed in rectangular shaped ferrocement counterfort retaining wall with $50 \mathrm{~mm}$ thickness, hence application of rectangular shaped ferrocement retaining wall with less thickness is unsafe

3. Direct stress values in stem at various heights of ferrocement arch stem and base retaining wall is $3.5 \%$ more in comparison with conventional $\mathrm{RCC}$ retaining wall and values are within permissible limits.

4. Direct stress values in counterforts at various heights of ferrocement arch stem and base retaining wall is $1.5 \%$ more in comparison with conventional RCC retaining wall and values are within permissible limits.

5. Deflection values of stem and counterforts in arch stem and base ferrocement counterfort retaining wall is found to be very less.

6. Cross section of structure in Ferrocement arch stem and base retaining structure is reduced significantly therefore found to be economical.

\section{REFERENCES}

1. Dr. B.N. Divekar, 2012 "Ferrocrete Technology: A Construction Manual", Sarvajeet Graphics, Karad, Maharashtra

2. N.Jayaramappa and Dr.H.Sharada Bai, "Evaluation of Strength and Modulus of Elasticity of Ferrocement Elements", International Journal of Scientific Research, Vol05, Issue-04.

3. HamidEskandari ${ }^{1}$, AmirhosseinMadadi $^{2}$ "Investigation of ferrocement channels using experimental and finite element analysis" by Engineering Science and Technology, an International Journal

4. Girish p. Dhotre, "Ferrocement retaining wall a case study" ferrocement society National conference2011,Pune

5. P. D. Hiwase, B.M. Anjankar and P.P. Dahale "Experimental study on settlement behaviour of pile raft foundation in dry sandy soil" International Journal of Civil Engineering and Technology (IJCIET), Volume 9, Issue 5, May 2018, Pages 1229-1236 Publisher IAEME Publication. 
6. P. D. Hiwase, Shashank Bisen and Pratik Surana "Adoption of Programming Codes in the Design of Earth Retaining Wall in Different Backfill Conditions' The International Journal of Engineering and Science (IJES) ISSN €: 2319 - 1813 ISSN (p): 23-19 - 1805 Volume 1, Issue THE IJES : Special Issue Archive 2018, Pages 47-53.

7. P. D. Hiwase, Sohail Khan and P Pachpor "Analysis and Design of Underground Retaining Wall by Using Beam and Column As Buttresses" International Journal for Science and Advance Research in Technology (IJSART), ISSN [ONLINE]: 2395-1052, Volume 3,Issue 5 , May- 2017, Pages 936-940.

8. IS:456-2000, plain and reinforced concrete-code of practice $\left(4^{\text {th }}\right.$ revision $)$, Bureau of Indian standards, New Delhi 